\title{
Light Environment Effect in the Sperm and Ribonucleic Acid Quality and Body Weight of Male Mus musculus
}

\author{
Evi Hanizar ${ }^{1 *}(\mathbb{D})$, Yung-Sen Huang ${ }^{2}$ (D) Tri Agus Siswoyo $^{3}$ D, Mohamad Syaifudin Aswan $^{1}$ (D) \\ ${ }^{1}$ Department of Biology Education, University of PGRI Agropuro Jember, Jember, Indonesia; ${ }^{2}$ Department of Life Science, \\ National University of Kaohsing, Kaohsiung, Taiwan; ${ }^{3}$ Center for Development of Advance Science and Technology, Universitas \\ Jember, Jember, Indonesia
}

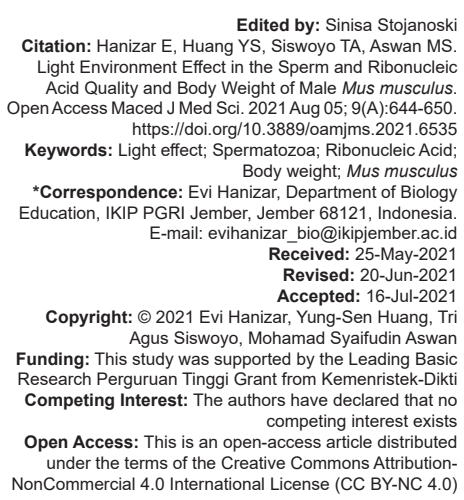

\section{Abstract}

BACKGROUND: The mice are categorized as the nocturnal animal meaning that most of the activity conducted in dark environment. However, the treatment of mice as the object studied in the laboratory often experiences the lack attention especially the treat to light exposure to mice during the investigation period which potentially affect the result.

AIM: The present study aims to investigate the effect of light environment in the sperm quality, RNA quality, and body weight of male Mus musculus.

METHODS: We compared in the mice the desired parameter onto the sample of 16 mice which kept in light and dark cages for 6 weeks.

RESULTS: The results indicated that there was a significant difference in the number of sperm, concentration, and purity of RNA between the mice exposed in dark and light environment. The average number of sperm from the ones kept in the dark was found twice as much as those in the light condition. The average RNA concentration in the dark was higher than in the light place but the RNA purity in the dark was lower than the light place. However, the motility and morphology of sperm was not showing any significancy different in both conditions.

CONCLUSION: The result proved that the natural light of cages for treating the mice in the laboratory influences the amount of sperm and the quality RNA. Therefore, the control of the light room in the experimental laboratory needs to be considered, especially during the further experiment which related to the quality of sperm, RNA, and body weight of mice.

\section{Introduction}

Spermatogenesis is controlled by a few genes and can be influenced by environmental factors that produce proteins with different functions. The environmental factors influence the gene expression by activating and deactivating genes to determine how an organism develops [1]. Various environmental factors have been used to determine their effect on the quality of sperm, ranging from the provision of certain foods, such as shellfish [2], [3], [4], Vitamins $C$ and $E$ [5], [6], [7], [8], chemical elements effects [9], [10], [11], mineral nutrients [12], [13], and photoperiodism [14]. The genetic studies on the effect of the low sperm quality on male infertility have been reported [15], [16], [17], [18], [19], [20].

The experimental studies in biological, medical, or pharmaceutical science mostly use mice (Mus musculus) as the object because they have DNA organization and gene expression comparable to humans. Moreover, their maintenance is relatively easy and inexpensive, involving a short period in life, having a rapid reproductive rate, and not requiring a large place [21]. The mice are determined as the nocturnal animal where most of their daily activities, including eating and drinking, are performed in the dark phase. However, the maintenance of these animals in the laboratory often lacks attention in terms of their characteristics. Most of researcher or student place the as-studied mice in a place with the light exposure. The effect of light exposure on the organism has been reported. It has been shown that night light can increase the risk of metabolic and neuroendocrine function disorders and impair reproductive function along with increased exposure [22]. This finding is supported by a study on students in Japan who were exposed to artificial light at night, influencing the reduction of their sleep duration [23]. Moreover, mice receiving a total of $24 \mathrm{~h}$ of light showed an increased depressive behavior [24].

The molecular study of the relationship between light and gene expression involved in regulating the biological functions of animals has not been fully explained yet. Sunlight exposure, including the lightdark cycle on the gene expression of PAX6 in the sea urchin Strongylocentrotus intermedius, shows a different expression in the pattern of $S$. intermedius between light and dark conditions. PAX6 is a gene that plays a role in the development and photoreception of eyes in animals. A daily cycle with an interval of $3 \mathrm{~h}$ shows a conflicting 
relationship between light intensity and gene expression. When light reaches its highest intensity, the PAX6 reaches the lowest level of relative gene expression proved that PAX6 as the light dependent genes.

A study of the regulation mechanism of gene expression in response to blue and red visible light exposure in zebrafish reveals that both lights induce the gene expression. The mechanism is determined by the promoter elements D-box enhancers. The mechanism of expression uses the extracellular signalregulated kinase (ERK) and mitogen-activated protein kinase (MAPK) pathways, which are highly dependent on the wavelength of light. Blue light activates gene transcription through a negative regulatory mechanism from the ERK/MAPK pathway, whereas red light does not use the pathway [26]. The finding of the effect of light in the gene expression of animals triggered us to investigate the effect of light exposure in the mice. The study would use three main parameters which were the sperm quality, ribonucleic acid (RNA) quality, and body weight of mice. The result was expected as the valuable information, especially for the researcher or student who conducted the research using the mice as the studied object in which the effect of light exposure could be as one of parameter that they should be considered.

\section{Materials and Methods}

This research was conducted in the laboratory of the Polytechnic Bioscience Jember-Indonesia. This research has been approved to use the animal as the object by the Research Ethics Commission from Brawijaya University with the Ethical Clearance number 1061-KEP-UB. The 4-week-old male of Mus musculus $(n=32)$ was obtained from the Laboratory of Animal Physiology, Islamic University of Malang. The mice maintenance cage was made of a plastic box covered by wire with a wood shavings base. After 1 week of acclimation, the mice were divided into two groups $(n=16)$, and four mice were placed in one cage with a total of four cages for one condition. The first group was taken care of by closing the cage with cardboard, whereas the cage of the other group was left open to let the light illuminate the cage. Both groups were placed in the same room where the light group received light from sunlight during the day and lamp during the night, whereas the dark group did not receive light during either day or night. The treatment was carried out for 6 weeks, and food and drink were provided ad libitum for both groups. Before observing the sperm, the animals were weighed using an analytical scale (Ohaus Adventurer) and scarified by cervical dislocation.

The mice epididymis was cut into small pieces and suspended with a sterile saline solution of $\mathrm{NaCl}$ $0.9 \%$. The number of sperm was observed by taking a $250-500 \mathrm{ml}$ suspension and etching at a Neubauer counting chamber under a microscope (Olympus Bx43 with DP22 camera). The observation guidelines were as follows: If there were $<10$ sperms in one box of the Neubauer counting chamber, 25 boxes were counted; if there were 10-40 sperms, 10 boxes were counted; and if there were $>40$ sperms, 5 boxes were counted. The total amount was calculated from the average number of sperm $\times$ dilution $\times 0.05 \times 10^{6}$. Sperm motility was calculated from the number of sperm moving forward divided by 100 sperm obtained from 4-6 fields of view under microscope $\times 100 \%$. The morphology of sperm was observed at a magnification of $\times 1000$ after making smear preparations and staining with absolute methanol for $5 \mathrm{~min}$, safranin for $5 \mathrm{~min}$, and three dyes of phosphate buffer and crystal violet for $5 \mathrm{~min}$. The normal sperm was identified as those with a hook-shaped head and a long straight tail.

The investigation of RNA quality used an RNA isolation kit (Invitrogen, Catalog No. 15596.026). The extraction process followed the manual procedure of the kit through the process of homogenization of 50-100 mg testes using Trizol reagent, RNA precipitation with isopropanol and then washing with $75 \%$ ethanol, and RNA solubilization with RNase-free water. The concentration of RNA was measured with a spectrophotometer (NanoDrop), and the purity was estimated by OD values at 260 and $280 \mathrm{~nm}$.

To maintain the stability of the sample quality, reverse transcription-polymerase chain reaction (PCR) using an RT-PCR kit (Invitrogen, Catalog no. 18080051) was performed to obtain cDNA through the stages of $10 \mu \mathrm{l}$ RNA heated at a temperature of $70^{\circ} \mathrm{C}$ for $10 \mathrm{~min}$ then transported in ice, and $10 \times$ buffer $(2 \mu \mathrm{l})$, $10 \mu \mathrm{m}$ deoxynucleotide triphosphates (dNTP; $2 \mu \mathrm{l}$ ), random hexamer $(1 \mu \mathrm{l})$, double-distilled water $\left(\mathrm{ddH}_{2} \mathrm{O}\right.$; $4 \mu \mathrm{l})$, and Dnase $(1 \mu \mathrm{l})$ reagent were added so that the total volume was $20 \mu \mathrm{l}$. The mixture was incubated at $37^{\circ} \mathrm{C}$ for $70 \mathrm{~min}$ and then transferred to a temperature of $75^{\circ} \mathrm{C}$ for $15 \mathrm{~min}$ and finally placed at $4^{\circ} \mathrm{C}$.

cDNA was checked using PCR primers for Dazl (Daz like), an autosomal gene in most mammals that play an important role in the early stages of spermatogenesis compared to DAZ on chromosome $Y$, and actin primer as an internal control gene. The reagents used were PCR mix (6.8 $\mu$; 10× buffer [200 $\mu \mathrm{l}]$, dNTP [100 $\mu \mathrm{l}$ ], dimethyl sulfoxide [40 $\mu \mathrm{l}]$, and $\mathrm{ddH}_{2} \mathrm{O}[1020 \mu \mathrm{l}]$ ), forward and reverse primers (each $1 \mu \mathrm{l})$, cDNA $(1 \mu \mathrm{l})$, and Taq polymerase $(0.2 \mu \mathrm{l})$; the total volume was $10 \mu \mathrm{l}$. PCR used a thermocycler (Biometra, model Tprofessional Basic Gradient 96) with the following program: Pre-denaturation at $95^{\circ} \mathrm{C}$ for $5 \mathrm{~min}$ (denaturation at $95^{\circ} \mathrm{C}$ for $30 \mathrm{~s}$, annealing at $60^{\circ} \mathrm{C}$ for $30 \mathrm{~s}$, and extension at $72^{\circ} \mathrm{C}$ for $30 \mathrm{~s}$ ) for 35 cycles and final extension at $72^{\circ} \mathrm{C}$ for $5 \mathrm{~min}$. The result of $\mathrm{PCR}$ was run by electrophoresis through a $1 \%$ agarose gel and visualized under a gel dock. All data were analyzed using statistical program $\mathrm{R}$ with 
the Shapiro-Wilk normality test and continued with the independent two-sample t-test.

\section{Results and Discussion}

Figure 1 shows the result of the observation of sperm quality from the mice which kept under light or dark maintenance includes the amount, motility, and morphology. The results indicated a signifycant difference $(p<0.05)$ in number of sperm, whereas motility and morphology were not significantly different $(p>0.05)$.

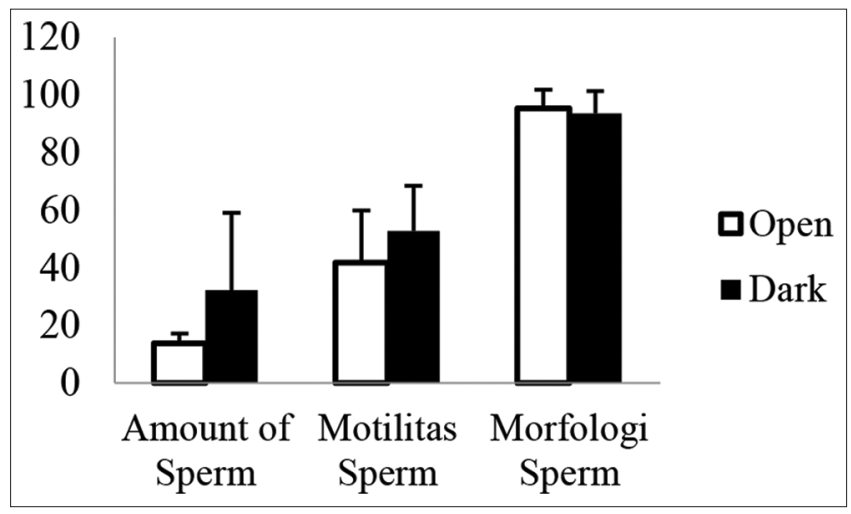

Figure 1: Sperm quality in the light (open) and dark group

The sperm were produced in the seminiferous tubules of the testes and refined through maturation in the epididymis until excreted. The process was controlled by several hormones involved in the hypothalamus-pituitary-testes pathway and can be influenced by various environmental factors. The hypothalamus produces gonadotropin-releasinghormone that triggers the hypophyses to secret the luteinizing hormone $(\mathrm{LH})$ and follicle-stimulating hormone $(\mathrm{FSH})$. LH affects Leydig cells to produce testosterone, whereas FSH stimulates Sertoli cells to release androgen-binding protein $(A B P)$. Both hormones play the main role in the process of spermatogenesis until the formation of mature sperm. The testosterone begins to play a role after the stage of primary spermatocytes, whereas FSH has a role in the final spermatid stage until the formation of a complete sperm. Through ABP, the testosterone is transported to the epididymis to be converted to dihydrotestosterone, which functions in the sperm maturation process so that it can move actively [27].

Exposing the light to the nocturnal animals initiated the stress to the animal and provided an impact on the pituitary-testes hormonal pathway. The stress response would trigger the release of the hormone corticosterone, whereas an increase in this hormone had a negative impact on the product inhibition of testosterone as described in previous research [28]. The effect can occur since the early involvement of testosterone due to the maintenance treatment of conditions in this study, as early as when the animals were 5 weeks old, whereas the age of adult mice ranges from 35 to 60 days. This finding was supported by a study in rats which states that psychological stress could potentially cause decrease in the quality and quantity of sperm [29], and a high level of stress decreases the amount of $38 \%$ of normal sperm in men [30]. This condition may explain the low number of sperm in the light group exposed to continuous light (Figure 1). The result was found similar with the research conducted by Wu et al. (2012); the chronic stress in the mice has a negative effect on female rat reproduction through a decrease in the expression of BDNF (brainderived neurotrophic factor) in antral follicles, the number of oocytes retrieved and the average formation of blastocysts [31]. The epidemiological research also reports that the stress associated with infertility influences the success of pregnancy in couples [32].

The sperm motility was a second parameter which investigated in this study, and motility determines the fertilization of the ovum. In the simple word, the motility indicated the progressive motility of sperm, namely, the ability to move fast or slow, forward, straight, zigzag, or circular in a large circular pattern [33]. The sperm movement was caused by the movement of the tail of sperm and affected by the energy contain in the sperm. In general, the morphology of sperm has the head and tail, which consists of the beginning (middle piece) and the end (end piece). The energy used by the sperm was derived from the conversion of ATP into ADP which was processed in the mitochondria at the base of the tail. The obtained energy was then transmitted to the tip so that the sperm can do the movement [34]

In contrast to the number of sperm, the results of the statistical analysis on motility had no significant difference $(p>0.05)$ between the two conditions. However, the average percentage of motile sperms which expose the light condition had a lower percentage $(41.66 \%)$ compared to the maintenance under dark condition $(52.83 \%)$. This was presumably due to the disruption of the availability of the stressrelated hormone testosterone exposure to light in the group under light condition. The sperm motility was obtained from the maturation process that occurred in the epididymis. However, the morphological structure of motile sperm in both conditions has the normal morphology. Therefore, this disorder might occur in glycolysis to produce energy (ATP).

The normal morphology of sperm in both conditions could potentially become the reason why the motility was not giving any significantly [27], [35], [36]. Along with sperm motility, the morphology analysis of the two maintenance conditions also indicated no significant difference. The average percentage of normal morphology from under light (95.31) and dark (93.50) conditions both had a percentage above $90 \%$, which was more than the normal standards of the 
World Health Organization (50\%). The normal criteria of sperm morphology were that the head resembles tapered curved hooks [37] and the tail was long and straight (Figure 2).
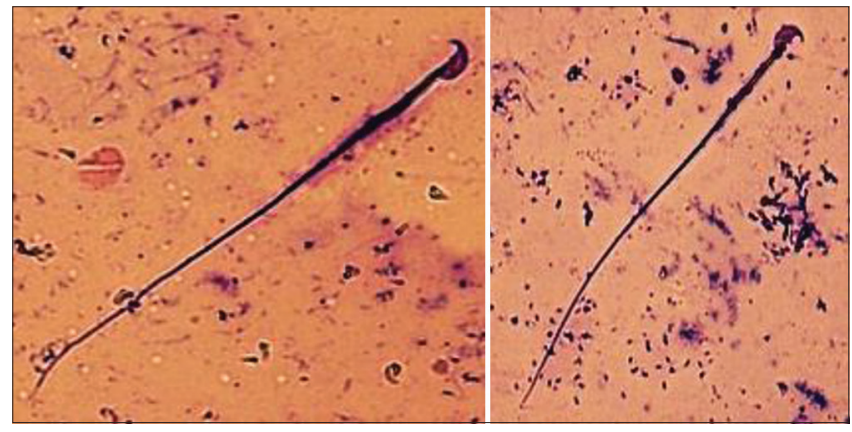

Figure 2: Normal sperm morphology

The completeness of the morphological structure occurs during sperm maturation in the epididymis resulting in progressively moving sperm [36] and then stored in the cauda epididymis to be excreted [38]. Abnormal sperm have double head, amorphous, micro, or without tail shape, loop shaped, corner, or double tail [39]. In this research, the observation obtained some abnormal sperm in a small number that have micro head-folded tail and loop-shaped tail, as shown in Figure 3. Theoretically, the abnormal conditions affect sperm motility but having a small number of abnormalities in the sperm could be negligible.

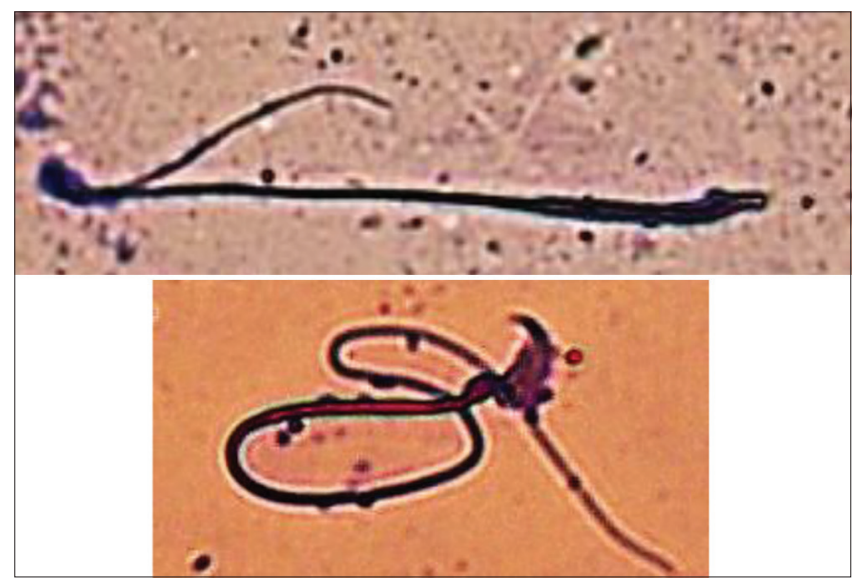

Figure 3: Abnormal sperm morphology. Left: Head amorphous and folded tail. Right: Loop-shaped tail

To be more specific in the presence of abnormal morphology, there were two kinds of sperm morphological abnormalities, namely, primary and secondary abnormalities. The primary abnormality was found as a head-shaped deformity, whereas secondary abnormality was a tail-shaped deformity. The primary abnormality occurred during spermatogenesis in the spermiogenesis stages, which was the change of spermatids into sperm in the seminiferous tubules, whereas secondary abnormality occurred due to interference during the process of sperm in the epididymis maturation [40].

The study was continued by analyzing the effect of light exposure in the RNA quality. The result showed that the light exposure in dark and light showed a significant difference $(p<0.05)$ between light and dark conditions. The RNA concentration was the amount of total RNA obtained from cells composing the testes. The average concentration of RNA under dark maintenance $(4.433 \pm 0.911 \mu \mathrm{g} / \mu \mathrm{l})$ was almost seven times more than that under light maintenance $(0.642 \pm 0.338 \mu \mathrm{g} / \mu \mathrm{l})$ (Figure 4).

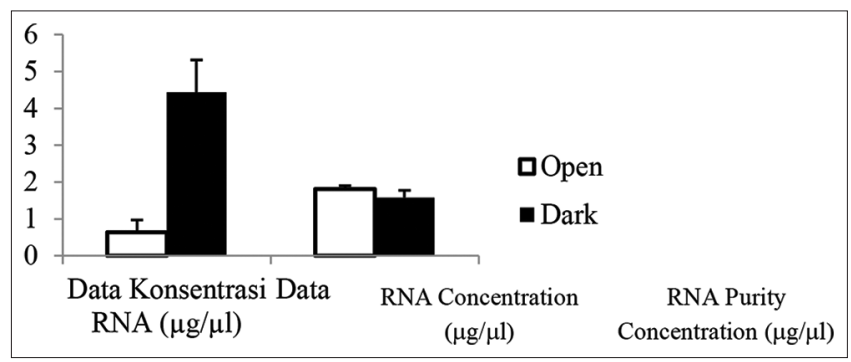

Figure 4: The concentration and purity of ribonucleic acid from light and dark group

In the study of gene expression, the study proved that the sample from the dark condition showed the more stable and higher compared to the sample obtained from the light condition. Exposure to light triggers various signaling pathways depending on the wavelength of light that will determine the level of regulation of gene expression. Blue and red light activate gene transcription using the promoter element D-box enhancer but are regulated by ERK-MAPK signaling pathway [41], [42]. The circadian rhythms are regulated by photoreceptors in the eye that absorbed blue light from the sun. All cells express genes that can maintain cellular time [43].

The results of this study are in accordance with the results of a previous study, although quantitatively RNA concentrations were measured and supported by qualitative visualization in the form of RT-PCR results, as shown in Figure 4. Dazl is a gene that plays a role in the early stage of spermatogenesis, specifically the formation of germ cells, so that the high concentration of RNA in the dark condition is in line with the high number of spermatozoa in the dark condition in this study.

Although both showed the difference, the purity of RNA from the light maintenance group had a higher value than the dark maintenance group. The RNA purity was calculated from the comparison of the absorbance at a wavelength of 260 and $280 \mathrm{~nm}$. The RNA is classified as pure quality if the ratio of the absorbance value A260/A280 is 1.8-2. The average value of RNA purity in the dark group (1.576) was lower than those in the light group (1.815). This finding showed that the light group had RNA purity according to the standards, whereas the dark group RNA indicates the presence of protein. This condition was consistent with the results of the previous studies, which showed that dark conditions increase the value of gene expression [25], although this study did not measure the protein produced.

The quality of RNA samples was shown from the results of electrophoresis after RT-PCR, as shown 
in Figure 5. Both samples were subjected to PCR with one pair of Dazl primer as a target gene and one pair of actin primers as an internal control gene. The lengths of amplicon were 700 and $100 \mathrm{bp}$, respectively. The figure seems to correspond to the quality and purity of the RNA sample, where the dark sample was clearer than the RNA sample obtained from the light condition sample, indicated that the one in light condition provided a higher quality and purity of RNA compared to the one obtained from the dark condition.

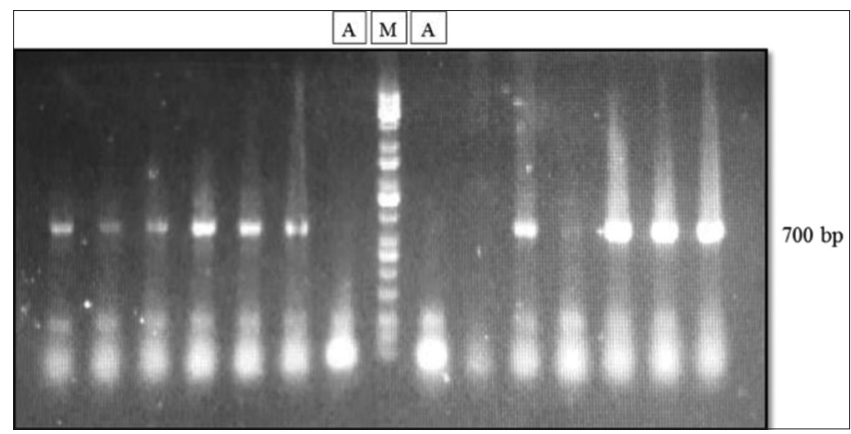

Figure 5: Polymerase chain reaction result for light (left) and dark (right) samples. $M=$ Marker $A=$ Actin

The study of the effect of light exposure on the body weight of mice did not show a significant difference $(p>0.05)$. However, the average weight of the dark group (30.43 $\mathrm{g}$ ) is higher than that of the light group $(27.62 \mathrm{~g})$, as shown in Figure 6. The animals in the light group received light all day, which was opposite to their normal nocturnal characteristics. This can result in a change in their feeding behavior. Furthermore, the continuous light exposure would trigger nocturnal animals to rest continuously resulting in less weight compared to the normal condition (dark). This result was consistent with a previous study [14], which showed that a group of animals exposed to bright light for $24 \mathrm{~h}$ has decreased body weight compared to a group of animals exposed to light for 18, 12, and $6 \mathrm{~h}$. The longer light exposure also caused the stress to the animals, and to compensate for the stress, it takes energy from the conversion of glucose or fat, causing weight loss [44], [45].

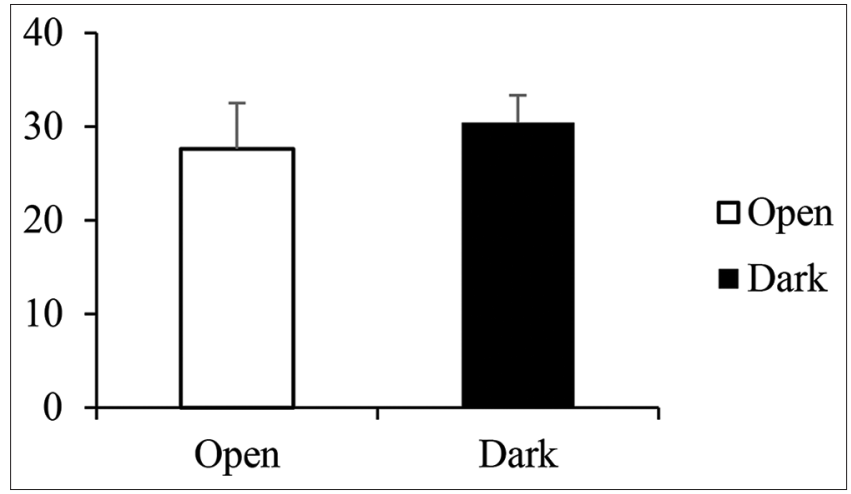

Figure 6: Average of body weight for light and dark group

\section{Conclusion}

The condition of light exposure provided an impact to the quality of mice sperm where the light exposure could less total amount of RNA but a better purity. Furthermore, the light exposure differentiated the feeding and resting behavior of sample, but the changes of behavior did not cause any significant different on sample weight. The result proved that the natural light of cages for treating the mice in the laboratory influences the amount of sperm and the quality RNA. Therefore, the control of the light room in the experimental laboratory needs to be considered, especially during the further experiment which related to the quality of sperm, RNA, and body weight of mice to avoid the biased study result.

\section{References}

1. Lobo I. Environmental influences on gene expression. Nat Educ. 2008;1(1):39.

2. Ferial EW, Muchlis A. (Anadara granosa L) macroscopic examination of human spermatozoa through nutrition of blood cockle's (Anadara granosa L.). J Sainsmat. 2013;2(1):1-13. https://doi.org/10.11648/j.ijnfs.20150404.16

3. Nirmalasari R. Pengaruh pemberian nutrisi kerang darah (Anadara granosa L). terhadap Tingkat Kepadatan Spermatozoa Mencit (Mus musculus L.). Bioma. 2017;2(1):9-14. https://doi. org/10.20956/bioma.v2i1.1351

4. Safitri N, Hanizar E. Efek konsumsi kerang bulu (Anadara antiquata) terhadap kuantitas dan kualitas spermatozoa Mus musculus, L. Al-Kauniyah. 2019;12(2):207-19. https://doi. org/10.15408/kauniyah.v12i2.11794

5. Khan RU, Javed I, Muhammad F. Effects of vitamins, probiotics, and protein level on semen traits and some seminal plasma macro and microminerals of male broiler breeders after zincinduced molting. Biol Trace Elem Res. 2012;148(1):44-52. https://doi.org/10.1007/s12011-012-9341-9 PMid:22318702

6. Mishra M, Acharya UR. Protective action of vitamins on the spermatogenesis in lead-treated Swiss mice. J Trace Elem Med Biol. 2004;18(2):173-8.

PMid:15646264

7. Mittal PK, Anand M, Madan AK, Yadav S, Kumar J. Antioxidative capacity of Vitamin E, Vitamin $C$ and their combination in cryopreserved Bhadavari bull semen. Vet World. 2014;7(12):1127-32. https://doi.org/10.14202/ vetworld.2014.1127-1131

8. Reza M, Hamid A. The effects of different levels of Vitamin E and Vitamin $\mathrm{C}$ in modified Beltsville extender on rooster postthawed sperm quality. Cell Tissue Banking. 2015;16(4):587-92. https://doi.org/10.1007/s10561-015-9506-9 PMid:25779925

9. Oliveira H, Spano M, Santos C, Pereira M. Lead chloride affects sperm motility and acrosome reaction in mice. Cell Bio Toxicol. 2009;25:345-53. https://doi.org/10.1007/s10565-008-9088-4 PMid:18594995 
10. Wroblewska UM, Kaminski P, Lakota P. Infuence of chemical elements on mammalian spermatozoa. Folia Biol. 2012;58(1):7-15.

\section{PMid:22464819}

11. Marettova E, Maretta M, Legath J. Effect of Cd with or wihtout Se suplementation on spermatogenesis and semen quality in the rooster (Gallus gallus). Avian Biol Res. 2013;6(4):275-80. https://doi.org/10.3184/175815513×13802978348434

12. Turgut G, Abban G, Turgut S, Take G. Effect of overdose Zinc on mouse testis and its relation with sperm count and motility. Biol Trace Elem Res. 2003;96(1-3):271-9. https://doi.org/10.1385/ bter:96:1-3:271

PMid:14716107

13. Tvrda E, Sikeli P, Lukacova J, Massanyi P, Lukac N. Mineral nutrients and male fertility. J Microbiol Biotechnol Food Sci. 2013;3(1):1-14

14. Ridwan A, Zakaria Z, Barlian A. Pengaruh fotoperiode terhadap respon stres dan parameter reproduksi pada mencit jantan (Mus musculus L.) galur Swiss Webster. J Matematika Sains. 2012;17(1):39-45. https://doi.org/10.36465/jkbth.v17i1.195

15. Ambulkar P, Chuadhary A, Waghmare J, Tarnekar A, Pal A. Prevalence of $Y$ chromosome microdeletions in idiopathic azoospermia cases in Central Indian men. J Clin Diagn Res. 2015;9(9):GC01-4. https://doi.org/10.7860/ jcdr/2015/15249.6515 PMid:26500921

16. Atia T, Abbas M, Ahmed AF. Azoospermia factor microdeletion in infertile men with idiopathic severe oligozoospermia or nonobstructive azoospermia. Afr J Urol. 2015;21:246-53. https://doi. org/10.1016/j.afju.2015.02.004

17. Asadi F, Gilani MA, Ghaheri A, Safari JR, Zamanian M. The pravelence of $Y$ chromosome microdeletions in Iranian infertile men with azoospermia and severe oligospermia. Cell J. 2017;19(1):27-33.

PMid:28367414

18. Beyaz CC, Gunes S, Onem K, Kulac T, Asci R. Partial deletions of Y-chromosome in infertile men with non-obstructive azoospermia and oligoasthenoteratozoospermia in a Turkish population. In Vivo. 2017;31(3):365-71. https://doi.org/10.21873/ invivo. 11068

PMid:28438864

19. Hanizar E. Delesi Region AZF (Azoospermia Factor) Dalam Kromosom Y Pria Infertil Berdasarkan Etnis di Indonesia (Disertasi). Surabaya, Indonesia: Universitas Airlangga; 2004.

20. Kim SY, Kim HJ, Lee BY, Park SY, Lee HS, Seo JT. $Y$ chromosome microdeletions in infertile men with nonobstructive azoospermia and severe oligozoospermia. J Reprod Infertil. 2017;18(3):307-15.

PMid:29062795

21. Kusumawati D. Bersahabat Dengan Hewan Coba. Yogyakarta: Gajah Mada University Press; 2004.

22. Navara KJ, Nelson RJ. The dark side of light at night: Physiological, epidemiological, and ecological consequences. J Pineal Res. 2007;43(3):215-24. https://doi. org/10.1111/j.1600-079x.2007.00473.x PMid: 17803517

23. Kohyama J. A newly proposed disease condition produced by light exposure during night: Asynchronization. Brain Dev. 2009;31(4):255-73. https://doi.org/10.1016/j. braindev.2008.07.006

PMid: 18757146

24. Fonken LK, Finy MS, Walton JC, Weil ZM, Workman JL, Ross J, et al. Influence of light at night on murine anxiety and depressivelike responses. Behav Brain Res. 2009;205(2):349-54. https://doi.org/10.1016/j.bbr.2009.07.001

\section{PMid:19591880}

25. Zhao C, Ji N, Sun P, Feng W, Wei J, Chang Y. Effect of light and covering behavior on PAX6 expression in the sea urchin Strongylocentrotusintermedius. PLoS One. 2014;9(10):e110895. https://doi.org/10.1371/journal.pone.0110895

26. Hirayama J, Miyamura N, Uchida $\mathrm{Y}$, Asaoka $\mathrm{Y}$, Honda $\mathrm{R}$, Sawanobori $\mathrm{K}$, et al. Common light signaling pathways controlling DNA repair and circadian clock entrainment in zebrafish. Cell Cycle. 2009;8(17):2794-801. https://doi. org/10.4161/cc.8.17.9447

PMid:19652538

27. Ramadhan PV, Rezano A, Permadi W. Correlation between sperm motility and morphology in the success rate of in vitro fertilization procedure. Althea Med J. 2016;3(4):520-5. https:// doi.org/10.15850/amj.v3n4.957

28. Hardy MP, Sottas CM, Ge R, McKittrick CR, Tamashiro KL, McEwen BS, et al. Trends of reproductive hormones in male rats during psychosocial stress: Role of glucocorticoid metabolism in behavioral dominance1. Biol Reprod. 2002;67(6):1750-5. https://doi.org/10.1095/biolreprod.102.006312

PMid: 12444049

29. Erris E, Harahap I. Pengaruh kebisingan terhadap Kuantitas dan kualitas spermatozoa tikus putih (Rattus norvegicus) jantan dewasa. Med Penelitian Pengembangan Kesehatan. 2014;24(3):123-8. https://doi.org/10.22435/mpk. v24i3.3646.123-128

30. Nordkap L, Jensen TK, Hansen ÅM, Lassen TH, Bang AK, Joensen UN, et al. Psychological stress and testicular function: A cross-sectional study of 1,215 Danish men. Fertil Steril. 2016;105(1):174-87.e1-2. https://doi.org/10.1016/j. fertnstert.2015.09.016

PMid:26477499

31. Wu CT, Gupta SK, Wang AZ, Lo SF, Kuo CL, Ko YJ, et al. Internal transcribed spacer sequence based identification and phylogenic relationship of herba dendrobii. J Food Drug Anal. 2012;20(1):143-51. https://doi.org/10.38212/2224-6614.2051

32. Boivin J, Schmidt L. Infertility-related stress in men and women predicts treatment outcome 1 year later. Fertil Steril. 2005;83(6):1745-52. https://doi.org/10.1016/j. fertnstert.2004.12.039

PMid: 15950646

33. World Health Organization. WHO Laboratory Manual for the Examination and Processing of Human semen. $5^{\text {th }}$ ed. Courtesy Switzerland, Switzerland: World Health Organization; 2010.

34. Akmal M, Masyitah D, Fitriani H. Epididimis dan perannya pada pematangan spermatozoa. Jesbio. 2015;4(2):1-9.

35. Tuset VM, Dietrich GJ, Wojtczak M, Slowinska M, Monserrat JD, Cieresszko A. Relationships between morphology, motility, and fertilization capacity in rainbow trout (Onchorhyncus mykiss) spermatozoa. J Appl Ichthyol. 2008;24:393-7. https://doi. org/10.1111/j.1439-0426.2008.01145.x

36. Borg C, Wolski K, Gibbs G, O'Bryan M. Phenotyping male infertility in the mouse: How to get the most out of a "nonperformer." Hum Reprod Update. 2010;16(2):205-24. https:// doi.org/10.1093/humupd/dmp032 PMid: 19758979

37. Nuraini TD, Kusmana E, Afifah. Penyuntikan ekstrak biji Carica papaya L. varietas cibinong pada Macaca fascicularis $L$. dan kualitas Sperm serta kadar hormon testosteron. Makara Kesehatan. 2012;16:9-16. https://doi.org/10.7454/msk. v16i1.1296

38. Bertol MA, Weiss RR, Thomaz-Soccol V, Kozicki LE, Fujita AS, de Abreu RA, et al. Viability of bull spermatozoa collected from the epididymis stored at $18-20^{\circ} \mathrm{C}$. Braz Arch Biol Technol. 2013;56(5):777-83. https://doi.org/10.1590/ s1516-89132013000500008 
39. Rahmi N. Pengaruh Pemberian Jus Buah Jambu Biji (Psidium Guajava) terhadap Kualitas dan Kuantitas Sperm Mencit Jantan yang telah Diinduksi Asap Rokok. Thesis. Jember, Indonesia: Universitas Jember; 2012. https://doi.org/10.26555/ bioedukatika.v2i1.4105

40. Ermayanti NG, Suarni NM. Kualitas Sperm mencit (Mus musculus L) setelah perlakuan infus kayu amargo (Quassia amara Linn) dan pemulihannya. J Biol. 2010;14(1):45-49.

41. Smith KW, Kay SA. Circadian rhythm genetics: From flies to mice. Nat Genet. 2000;26(1):23-7.

PMid:10973243

42. Mracek P, Pagano C, Frohlich N, Idda ML, Cuesta IH, Olmeda JF et al. ERK signaling regulates light-induced gene expression via D-box enhancers in a differential wavelength-dependent manner. PLoS One. 2013;8(6):e67858. https://doi.org/10.1371/ journal.pone. 0067858

PMid:23840779

43. Holick MF. Biological effect of sunlight, ultraviolet radiation, visible light, infrared radiation, and Vitamin $D$ for health. Antic Res. 2016;36(3):1345-56. PMid:26977036

44. Robert C, Troop N, Connan F, Treasure J, Campbell IC. The effects of stress on body weight: biological and psychological predictors of change in BMI. Obesity. 2007;15(12):3045-55. https://doi.org/10.1038/oby.2007.363

PMid:18198314

45. Rabasa C, Dickson SL. Impact of stress on metabolism and energi balance. Behav Sci. 2016;9:71-7. 